\title{
Pengaruh Tekanan Ketaatan, Pengetahuan, Dan Pengalaman Auditor Terhadap Audit Judgment Lambok DR Tampubolon ${ }^{1}$
}

\author{
Fakultas Ekonomi dan Bisnis Universitas Krida Wacana
}

\section{A R T I C L E I N F O}

\section{Article history:}

Received 29 Oktober 2018

Revised 28 November 2018

Accepted 26 Desember 2018

Key words:

Obedience Pressure, Knowledge, Auditor Experience, and Audit Judgment.

\begin{abstract}
A B S T R A C T
This research is quantitative research. The data used in this study is primary data by distributing questionnaires to public accounting firms domiciled in DKI Jakarta. The population in this study were auditors who worked in the Public Accounting Office. Questionnaires were distributed as many as 130 questionnaires and data that could be processed as many as 100 questionnaires. Data is processed using the help of SPSS 23. The purpose of this study is to examine the effect of auditor compliance, knowledge and experience on audit judgment. From a sample of 17 public accounting firms in DKI Jakarta, this study shows that: (1) obedience pressure has a significant positive effect on audit judgment, (2) knowledge has a significant positive effect on judgment audits, and (3) auditor experience has no effect on judgment audit.
\end{abstract}

\begin{abstract}
A B S T R A K
Penelitian ini merupakan penelitian kuantitatif. Data yang digunakan dalam penelitian ini merupakan data primer dengam menyebar kuesioner kepada kantor akuntan publik yang berdomisili di DKI Jakarta. Populasi pada penelitian ini adalah auditor yang bekerja di Kantor Akuntan Publik. Kuesioner yang disebar sebanyak 130 kuesioner dan data yang bisa diolah sebanyak 100 kuesioner. Data diolah dengan menggunakan bantuan software SPSS versi 23. Tujuan dari penelitian ini adalah untuk menguji pengaruh tekanan ketaatan, pengetahuan dan pengalaman auditor terhadap audit judgement. Dari sampel 17 kantor akuntan publik yang berada di DKI Jakarta, penelitian ini menunjukan hasil bahwa: (1) tekanan ketaatan berpengaruh positif signifikan terhadap audit judgement, (2) pengetahuan berpengaruh positif signifikan terhadap audit judgement, dan (3) pengalaman auditor tidak berpengaruh terhadap audit judgement.
\end{abstract}

dengan teknik off-balance sheet utang senilai US \$

\section{INTRODUCTION}

Masyarakat sedang mengalami krisis kepercayaan terhadap profesi akuntan dalam melakukan audit laporan keuangan. Ini disebabkan karna terjadinya kasus kegagalan audit dalam beberapa dekade belakangan ini. Tercatat telah terdapat 51 kasus gagal audit besar, dari tahun 1986 dengan sampai tahun 2010. Kasus gagal audit ini tidak hanya menimpa kantor akuntan besar Big4 tetapi juga praktik perorangan lainnya (Fitriani dan Daljono,2012).

Ariyantini et.,al (2014) menyatakan bahwa kasus Enron disebabkan karena manajemen Enron telah melakukan window dressing dengan memanipulasi angka - angka laporan keuangan agar kinerjanya terlihat baik. Dalam hal ini, pendapatan dinaikkan sebesar US \$ 600 juta dan
1,2 miliar disembunyikan. Auditor Enron, Arthur Andersen, juga ikut disalahkan karena kasus gagal audit ini.

Kasus gagal audit ini menimbulkan dampak seperti tuntutan hukum, hilangnya profesionalisme, dan hilangnya kepercayaan publik. Kasus gagal audit ini juga mempertaruhkan reputasi seorang auditor dari akuntan publik. Kunci utama dalam mempertahankan reputasi auditor adalah melakukan pencegahan terhadap terjadinya kasus kegagalan audit.

Para auditor harus senantiasa menggunakan profesional judgement mereka dalam segala proses audit karena dalam Standar Pekerjaan Lapangan No.1 (SPAP, 2011) disebutkan bahwa pekerjaan harus direncanakan sebaik-baiknya. Dimana 
pekerjaan audit yang dilaksanakan baik dalam tahap perencanaan maupun dalam tahap supervisi harus melibatkan profesional judgment (Fitriani dan Daljono, 2012). Dalam Standar Profesional Akuntan Publik (SPAP) pada seksi 341 menyatakan bahwa dasar dari audit judgement mengenai kemampuan suatu usaha untuk mempertahankan kelangsungan hidupnya adalah ada tidaknya kesangsian auditor terhadap kemampuan suatu usaha untuk mempertahankan kelangsungan hidupnya dalam satu periode.

Menurut Fitriana et.,al (2014), Audit judgement merupakan suatu pertimbangan yang mempengaruhi dokumentasi bukti dan keputusan yang dibuat oleh auditor. Judgement merupakan proses yang terus menerus dalam perolehan informasi (termasuk umpan balik dan tindakan sebelumnya), pilihan untuk bertindak atau tidak bertindak, serta penerimaan informasi lebih lanjut oleh auditor. Cara pandang auditor dalam menanggapi informasi berhubungan dengan tanggung jawab dan risiko audit yang akan dihadapi oleh auditor sehubungan dengan judgement yang dibuatnya (Jamilah et.,al 2007).

Faktor-faktor yang mempengaruhi kinerja seorang auditor dalam pembuatan audit judgment ini antara lain meliputi faktor gender, tekanan ketaatan, dan kompleksitas tugas (Jamilah et.,al 2007). Menurut Yendrawati dan Mukti (2015) faktor yang mempengaruhi kinerja seorang auditor adalah gender, pengalaman auditor, kompleksitas tugas, tekanan ketaatan, kemampuan kerja dan pengetahuan auditor. Dalam penelitian ini faktor yang diteliti adalah tekanan ketaatan, pengetahuan dan pengalaman auditor.

Tekanan ketaatan merupakan salah satu faktor yang mempengaruhi audit judgement. Dalam teori ketaatan dijelaskan bahwa tekanan ketaatan adalah kekuasaan yang dimiliki individu yang merupakan sumber yang dapat mempengaruhi perilaku orang lain dengan perintah yang diberikannya. Dengan kata lain, auditor yang merasa berada dibawah tekanan akan menunjukan perilaku disfunctional dengan menyetujui kesalahan ataupun pelanggaran etika, termasuk dalam pembuatan judgement. Tekanan ketaatan yang dirasakan oleh auditor dapat berasal dari atasan ataupun dari klien. Tekanan ketaatan yang berasal dari atasan dapat berupa budget waktu, tenggat waktu dan justifikasi dalam melakukan audit. Sedangkan tekanan yang berasal dari klien seperti tekanan personal, emosional atau keuangan yang dapat mengakibatkan independensi seorang auditor berkurang dan mempengaruhi kualitas audit serta judgement auditor.

Faktor lain yang mempengaruhi audit judgement adalah pengetahuan auditor. Auditor harus memiliki pengetahuan pengauditan baik secara umum dan khusus, pengetahuan mengenai bidang auditing dan akuntansi serta auditor juga harus memahami industri dari perusahaan yang sedang diperiksanya. Semakin sering seorang auditor mengikuti pelatihan, seminar dan sertifikat yang dimiliki semakin banyak auditor diharapkan dapat semakin berkompeten dalam melaksanakan tugasnya. Perbedaan pengetahuan diantara auditor akan mempengaruhi cara auditor menyelesaikan pekerjaannya.

Selain tekanan ketaatan dan pengetahuan auditor, pengalaman auditor merupakan salah satu faktor yang diduga dapat mempengaruhi audit judgment. Pengalaman auditor dinilai memiliki pengaruh yang besar terhadap penilaian kinerja auditor. Menurut Putra dan Rani (2016) Auditor yang tidak berpengalaman akan melakukan atribusi kesalahan lebih besar dibandingkan dengan auditor yang berpengalaman. Pengalaman auditor akan menjadi bahan pertimbangan yang baik dalam mengambil keputusan dalam tugasnya. Pengalaman dapat dilihat dari lamanya si auditor menggeluti profesi nya sebagai auditor. Dan pengalaman juga dapat ditentukan oleh banyaknya tugas pemeriksaan yang pernah dilakukan atau banyaknya jenis perusahaan yang telah diaudit.

Penelitian sebelumnya mengenai audit judgement telah dilakukan oleh beberapa peneliti. Menurut penelitian Fitriana et.,al (2014), dimana dalam penelitian ini menunjukkan bahwa tekanan ketaatan berpengaruh signifikan terhadap audit judgement. Penelitian ini juga diperjelas oleh Jamilah et.,al (2007) dan Yustrianthe (2012) yang menyatakan bahwa terdapat pengaruh yang signifikan antara tekanan dari atasan atau klien terhadap audit judgement. Namun terjadi perbedaan pendapat didalam penelitian Fitriani dan Daljono (2012) dan Sari (2016) yang menyatakan bahwa tidak terdapat pengaruh yang signifikan antara tekanan ketaan terhadap audit judgment.

Penelitian lain tentang audit judgment juga dilakukan oleh Fitriani dan Daljono (2012) yang menguji pengaruh pengetahuan terhadap audit judgement yang diberikan oleh auditor, hasil penelitian ini menunjukkan adanya pengaruh signifikan dari pengetahuan auditor terhadap audit judgement. Penelitian ini konsisten dengan penelitian Sila et.,al (2015) yang menyatakan 
adanya pengaruh antara pengetahuan auditor terhadap audit judgement. Hal ini menunjukkan bahwa apabila semakin meningkat pengetahuan auditor maka audit judgement yang diberikan juga akan semakin baik. Tetapi penelitian ini tidak sejalan dengan penelitian yang dilakukan oleh S. Ika et.,al (2011) karena dinyatakan didalam penelitian tersebut bahwa tidak terjadi pengaruh yang signifikan antara pengetahuan auditor terhadap audit judgement. Kondisi ini menunjukan bahwa tidak ada jaminan dengan banyaknya pengetahuan yang dimiliki si auditor akan memberikan audit judgment yang tepat. Menurut penelitian Ariyantini et.,al (2014) dikatakan bahwa semakin tinggi pengalaman auditor maka audit judgement yang dihasilkan akan semakin tepat. Hasil penelitian ini menunjukkan adanya pengaruh signifikan antara pengalaman auditor dan audit judgement. Hal ini bertentangan dengan penelitian Yustrianthe (2012) yang mengatakan bahwa tidak terjadi pengaruh yang signifikan antara pengalaman auditor senior dan auditor junior terhadap audit judgement.

\section{THEORETICAL FRAMEWORK AND HYPOTHESES}

\section{Audit Judgement}

Standar Profesional Akuntan Publik (SPAP) pada seksi 341 menyebutkan bahwa audit judgement atas kemampuan kesatuan usaha dalam mempertahankan kelangsungan hidupnya harus berdasarkan pada ada tidaknya sanksi dalam diri auditor itu sendiri terhadap kemampuan suatu kesatuan usaha dalam mempertahankan kelangsungan hidupnya dalam periode satu tahun sejak tanggal laporan keuangan auditan (Institut Akuntan Publik Indonesia, 2011).

Proses judgement tergantung pada kedatangan informasi sebagai suatu proses unfolds. Kedatangan informasi bukan hanya mempengaruhi pilihan, tetapi juga mempengaruhi cara pilihan tersebut dibuat. Setiap langkah, didalam proses incremental judgement jika informasi terus menerus datang, akan muncul pertimbangan baru dan keputusan/pilihan baru. Sebagai gambaran, akuntan publik mempunyai tiga sumber informasi yang potensial untuk membuat suatu pilihan : (1) teknik manual, (2) referensi yang lebih detail dan (3) teknik keahlian. Berdasarkan proses informasi dari ketiga sumber tersebut, akuntan mungkin akan melihat sumber yang pertama, bergantung pada keadaan perlu tidaknya diperluas dengan sumber informasi kedua, atau dengan sumber informasi yang ketiga, tetapi jarang memakai keduanya. Akuntan sering berhadapan dengan keputusan yang hasilnya tidak cukup oleh kode etik maupun oleh standar akuntansi berterima umum. Pertimbangan utama dalam keputusan adalah etika, walaupun seringkali melibatkan berbagai macam konflik kepentingan. Judgement akuntan profesional dapat dirusak oleh konflik kepentingan. Terdapat dua konflik kepentingan, yaitu real conflict dan latent conflict. Real conflict adalah konflik yang mempunyai pengaruh pada masalah judgment yang ada, sedangkan latent conflict adalah konflik yang bisa mempengaruhi judgement di masa mendatang (Jamilah et.,al 2007).

\section{Tekanan Ketaatan}

Puspitasari (2014) mengatakan bahwa " Tekanan Ketaatan merupakan tekanan yang muncul dari dalam individu karena mendapat perintah dari individu lain, baik atasan maupun klien entitas." Hal ini pasti akan menimbulkan tekanan pada diri auditor itu sendiri untuk menuruti atau tidak menuruti keinginan klien ataupun atasannya. Oleh sebab itu, seorang auditor seringkali dihadapkan pada dilema penerapan standar profesi auditor dalam pengambilan keputusannya. Tekanan - tekanan dalam penugasan audit ini bisa dalam bentuk budget waktu, deadline, justifikasi ataupun akuntabilitas dari pihak - pihak yang memiliki kekuasaan dan kepentingan seperti partner ataupun klien (Fitriana et.,al 2014). Dalam Penelitian Jamilah et.,al (2007) dikatakan bahwa bawahan yang mengalami tekanan ketaatan dari atasan akan mengalami perubahan psikologis dari seseorang yang berperilaku autonomis menjadi perilaku agen. Perubahan perilaku ini terjadi karena bawahan tersebut merasa menjadi agen dari sumber kekuasaan, dan dirinya terlepas dari tanggung jawab atas apa yang dilakukannya.

\section{Pengetahuan}

Pengetahuan (bahasa Yunani = episteme, dan Inggris $=$ knowledge), merupakan salah satu kemampuan khas manusia, sebagai mahluk berpikir (homosapiens) (Aholiab Watloly, 2013:19). Seseorang yang melakukan pekerjaan sesuai dengan pengetahuan yang dimilikinya akan memberikan hasil yang lebih baik daripada mereka yang tidak memiliki pengetahuan yang cukup memadai akan tugasnya. Auditor harus telah menjalani pendidikan dan pelatihan teknis yang cukup dalam praktik akuntansi dan teknik auditing 
sehingga mampu menjalankan tugasnya dengan baik dan tepat (Yendrawati dan Mukti, 2015).

Tingkat Pengetahuan yang dimiliki auditor merupakan hal yang sangat penting yang dapat mempengaruhi auditor dalam mengambil keputusan. Pengetahuan merupakan salah satu kunci keefektifan kerja. Dengan tingkat pengetahuan yang tinggi yang dimiliki oleh seorang auditor, auditor tidak hanya akan bisa menyelesaikan sebuah pekerjaan audit secara efektif tetapi juga akan mempunyai pandangan yang lebih luas mengenai berbagai hal. Auditor yang memiliki tingkat pengetahuan yang tinggi dapat mendeteksi sebuah kesalahan (Fitriani dan Daljono, 2012).

\section{Pengalaman Auditor}

Pengalaman adalah keseluruhan pelajaran yang dipetik oleh seseorang dari peristiwa peristiwa yang dialami dalam perjalanan hidupnya. Seorang karyawan yang memiliki pengalaman kerja yang tinggi akan memiliki keunggulan dalam beberapa hal : 1) mendeteksi kesalahan, 2) memahami kesalahan, dan 3) mencari penyebab munculnya kesalahan (Yendrawati dan Mukti, 2015).

Pengalaman auditor dapat juga ditentukan oleh banyaknya tugas pemeriksaan yang pernah dilakukan atau banyaknya jenis perusahaan yang telah diaudit. Semakin banyak variasi jenis pekerjaan ataupun jenis perusahaan yang diperiksanya, maka auditor tersebut dinilai semakin berpengalaman. Semakin berpengalaman seorang auditor dalam bidangnya, maka auditor dinilai mempunyai pengetahuan lebih dalam mengidentifikasi bukti atau informasi yang relevan dan tidak relevan untuk mendukung penugasan auditnya termasuk dalam pembuatan audit judgement-nya (Yustrianthe, 2012).

\section{Kerangka Pikir}

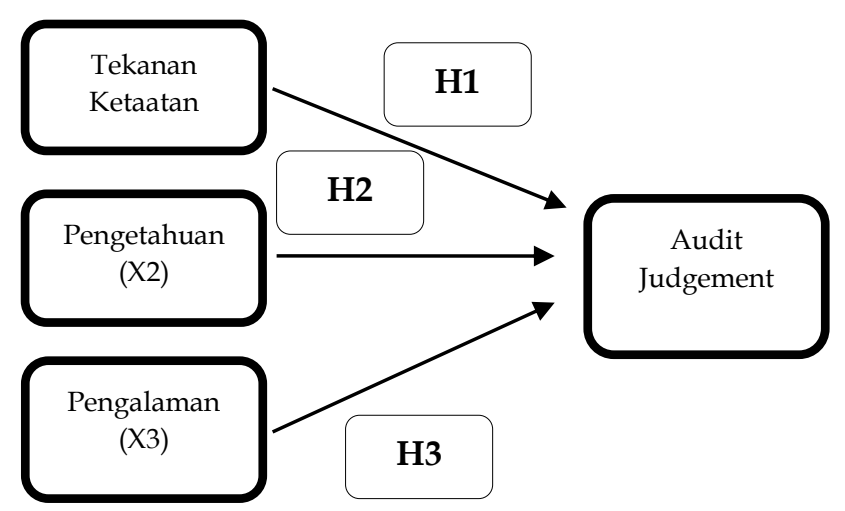

\section{DATA ANALYSIS AND DISCUSSION Hasil Uji Reliabilitas}

Uji reliabilitas digunakan untuk mengetahui konsistensi alat ukur, apakah alat ukur tersebut dapat diandalkan atau dipercaya dalam mengukur variabel. Menurut Ghozali (2013), kuesioner penelitian ini dapat dinyatakan reliabel apabila nilai Cronbach's Alpha diatas 0,6. Hasil pengujian reabilitas dari Tekanan Ketaatan (X1), Pengetahuan Auditor (X2), Pengalaman Auditor (X3) dan Audit Judgement (Y) dapat dilihat dari tabel dibawah ini.

\begin{tabular}{|c|c|c|}
\hline \multicolumn{3}{|c}{ Uji Reliabilitas } \\
\hline $\begin{array}{c}\text { Variabel } \\
\text { (X1) }\end{array}$ & $\begin{array}{c}\text { Cronbach's } \\
\text { Alpha }\end{array}$ & Keterangan \\
\hline $\begin{array}{c}\text { Pengetahuan } \\
\text { Auditor (X2) }\end{array}$ & 0,840 & Reliabel \\
\hline $\begin{array}{c}\text { Pengalaman Auditor } \\
\text { (X3) }\end{array}$ & 0,7932 & Reliabel \\
\hline Audit Judgment (Y) & 0,653 & Reliabel \\
\hline
\end{tabular}

Sumber : Data primer yang diolah

Dari tabel diatas dapat dilihat nilai Cronbach's Alpha dari variabel tekanan ketaatan sebesar 0,840 lebih besar dari 0,6, hal tersebut membuktikan bahwa variabel tekanan ketaatan dapat dikatakan reliabel, untuk variabel pengetahuan auditor memiliki nilai Cronbach's Alpha sebesar 0,932 lebih besar dari 0,6, hal tersebut membuktikan pengetahuan auditor dapat dikatakan reliabel, untuk variabel pengalaman auditor memiliki nilai Cronbach's Alpha sebesar 0,792 lebih besar dari 0,6, hal tersebut membuktikan pengalaman auditor dapat dikatakan reliabel, dan untuk variabel audit judgment memiliki nilai Cronbach's Alpha sebesar 0,653 lebih besar dari 0,6, hal tersebut membuktikan audit judgment dapat dikatakan reliabel. Dengan demikian, pernyataan kuesioner dari variabel $\mathrm{X} 1$, $\mathrm{X} 2$, X3, dan $\mathrm{Y}$ telah memenuhi persyaratan reliabilitas.

\section{Uji Normalitas}

Menurut Ghozali (2013) Uji Normalitas digunakan untuk menguji apakah dalam model regresi, variabel residual atau pengganggu memiliki distribusi normal atau tidak. Dalam penelitian ini uji normalitas menggunakan alat analisis berupa 
SPSS 23 (statistical package for social science 23). Uji normalitas dilakukan menggunakan uji statistik non-parametrik Kolmogorov-Smirnov (K-S). Apabila nilai Kolmogorov-Smirnov memiliki nilai lebih besar dan signifikan dibandingkan tingkat kepercayaan 5\% maka dapat dinyatakan data dalam kuesioner ini mempunyai distribusi normal.

Uji Normalitas

One-Sample Kolmogorov-Smirnov Test

\begin{tabular}{|c|c|c|}
\hline & & $\begin{array}{l}\text { Unstandardized } \\
\text { Residual }\end{array}$ \\
\hline $\mathrm{N}$ & & 100 \\
\hline \multirow[t]{3}{*}{ Normal Parameters ${ }^{a, b}$} & Mean & 0000000 \\
\hline & Std. & 2 73707850 \\
\hline & Deviation & 2,13792000 \\
\hline \multirow[t]{3}{*}{ Most Extreme Differences } & Absolute & ,056 \\
\hline & Positive & , 052 \\
\hline & Negative &,- 056 \\
\hline Test Statistic & & ,056 \\
\hline Asymp. Sig. (2-tailed) & & ,200c,d \\
\hline
\end{tabular}

a. Test distribution is Normal.

b. Calculated from data.

c. Lilliefors Significance Correction.

$\mathrm{d}$. This is a lower bound of the true significance.

Sumber : Output SPSS 23.0 for windows

Hasil output dari uji normalitas pada tabel diatas memperlihatkan bahwa nilai signifikansi Kolmogorov-Smirnov sebesar 0,200, ini menunjukan bahwa nilai signifikansi diatas 0,05 sehingga dapat disimpulkan data pada kuesioner mempunyai distribusi normal.

\section{Uji Multikolinearitas}

Uji multikolinearitas bertujuan untuk menguji apakah model regresi berkorelasi dengan variabel independen. Model regresi dikatakan baik apabila tidak terjadi korelasi dengan variabel independen. Data pada kuesioner dikatakan mengalami multikolinearitas jika nilai tolerance dibawah 0,1 dan nilai VIF lebih dari 10 . Berdasarkan hasil uji multikolinearitas yang telah dilakukan maka dapat dilihat nilai tolerance dan VIF masing-masing variabel pada tabel dibawah.
Uji Multikolinearitas

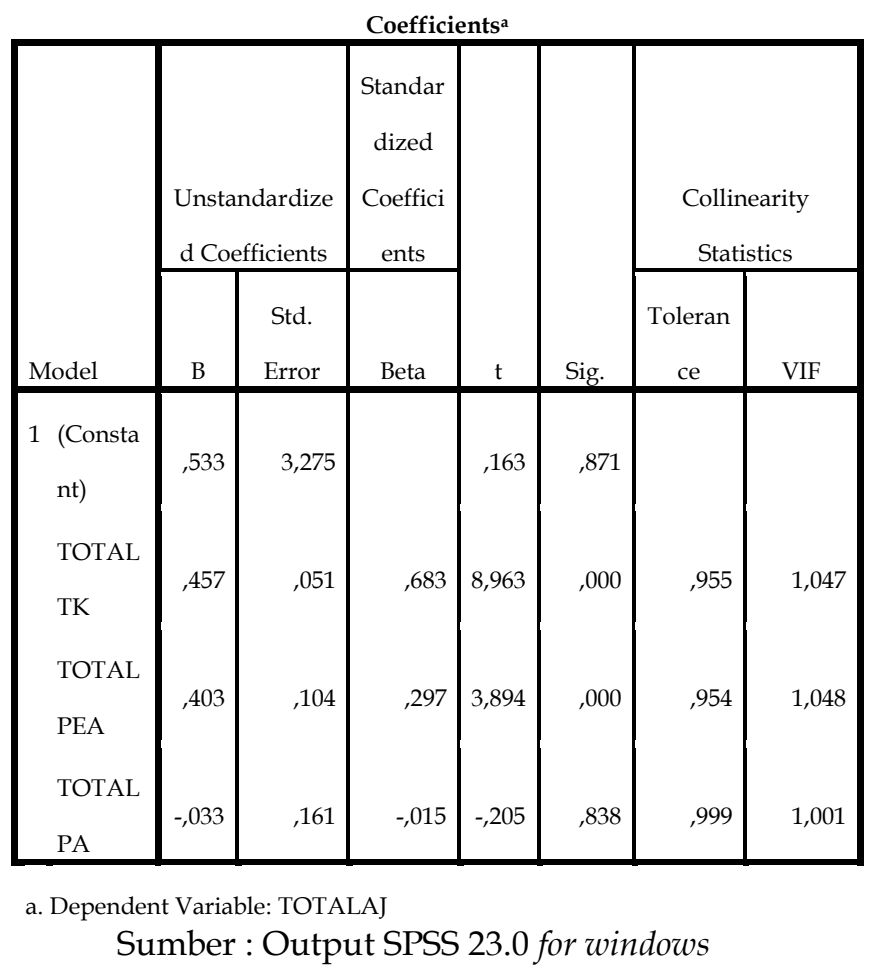

Berdasarkan tabel diatas bahwa nilai tolerance dari variabel tekanan ketaatan sebesar 0,955 lebih besar dari 0,1, untuk nilai tolerance dari variabel pengetahuan auditor sebesar 0,954 lebih besar dari 0,1 , untuk nilai tolerance dari variabel pengalaman auditor sebesar 0,999 lebih besar dari 0,1 dan nilai VIF dari variabel tekanan ketaatan sebesar 1,047 lebih kecil dari 10, untuk nilai VIF dari variabel pengetahuan auditor sebesar 1,048 lebih kecil dari 10, untuk nilai VIF dari variabel pengalaman auditor sebesar 1,001 lebih kecil dari 10, dari hasil tersebut dapat disimpulkan variabel tekanan ketaatan, pengetahuan auditor dan pengalaman auditor tidak mengalami multikolinearitas.

\section{Uji Heteroskedastisitas}

Uji heteroskedastisitas ini berguna untuk mengetahui apakah model regresi terjadi ketidaksamaan varian dari residual satu pengamatan ke pengamatan yang lain (Ghozali, 2013). Model regresi dikatakan baik apabila tidak terjadi heteroskedastisitas. Hasil penelitian pada kuesioner dinyatakan terjadi heteroskedastisitas, apabila variasi variabel satu pengamatan dengan pengamatan yang lain berbeda. 
Uji Heteroskedastisitas

Scatterplot

Dependent Variable: TOTALA

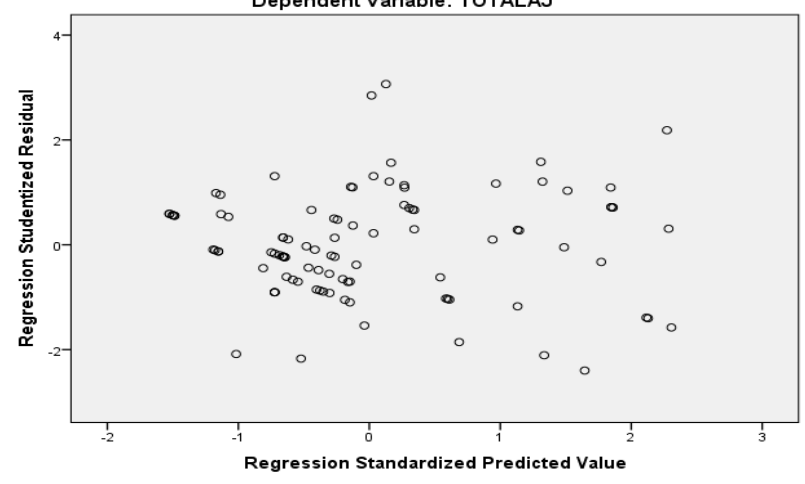

Sumber : Output SPSS 23.0 for windows

Berdasarkan hasil uji heteroskedastisitas diatas maka dapat dilihat titik - titik menyebar secara acak pada grafik scatterplot. Dengan demikian dapat dinyatakann bahwa pada penelitian ini tidak terjadi heteroskedastisitas.

\section{Hasil Pengujian Hipotesis}

Regresi Linier Berganda

Analisis data dilakukan dengan model regresi linier untuk mengukur satu variabel dependen dan variabel independen. Dalam penelitian ini uji regresi linier berganda menggunakan alat analisis berupa SPSS 23 (statistical package for social science 23).

\section{Hasil Uji Analisis Regresi Linier Berganda}

Coefficients ${ }^{\mathrm{a}}$

\begin{tabular}{|c|c|c|c|c|c|}
\hline \multirow[b]{2}{*}{ Model } & \multicolumn{2}{|c|}{$\begin{array}{l}\text { Unstandardized } \\
\text { Coefficients }\end{array}$} & \multirow{2}{*}{$\begin{array}{c}\text { Standardized } \\
\text { Coefficients } \\
\text { Beta }\end{array}$} & \multirow[b]{2}{*}{$\mathrm{t}$} & \multirow[b]{2}{*}{ Sig. } \\
\hline & B & Std. Error & & & \\
\hline 1 (Constant) &, 533 & 3,275 & & 163 & 871 \\
\hline TOTALTK & ,457 & 051 & ,683 & 8,963 & ,000 \\
\hline $\begin{array}{l}\text { TOTALPE } \\
\text { A }\end{array}$ & ,403 & 104 & ,297 & 3,894 & ,000 \\
\hline TOTALPA &,- 033 & 161 &,- 015 &,- 205 & ,838 \\
\hline
\end{tabular}

a. Dependent Variable: TOTALAJ

Sumber : Output SPSS 23.0 for windows
Dari tabel diatas dapat disimpulkan persamaan regresi dalam bentuk Unstandardized Coefficients sebagai berikut:

$\mathrm{AJ}=0,533+0,457 \mathrm{TK}+0,403 \mathrm{PEA}-0,033 \mathrm{PA}+\mathrm{e}$

Keterangan :

a : Konstanta

AJ : Audit Judgement

TK : Tekanan Ketaatan

PEA : Pengetahuan Auditor

PA : Pengalaman Auditor

e : Error

Penjelasan mengenai analisis regresi linier berganda adalah sebagai berikut :

1. Konstanta (a) menunjukan nilai dari Audit Judgement. Nilai konstanta dari model regresi adalah sebesar 0,533. Ini berarti apabila Tekanan Ketaatan (X1), Pengetahuan (X2), dan Pengalaman Auditor (X3) memiliki nilai 0 , maka Audit Judgement ( $\mathrm{Y}$ ) nilainya adalah 0,533 .

2. Variabel Tekanan Ketaatan (X1) memiliki nilai $\mathrm{t}$ sebesar 8,963, nilai koefisiensi $\beta$ sebesar 0,457. Hal ini menunjukan bahwa koefisien variabel (X1) berpengaruh positif terhadap audit judgement (Y). Artinya bahwa auditor junior dalam kondisi adanya tekanan dari klien dan perintah dari atasan akan mentaati perintah tersebut dan auditor akan berperilaku menyimpang dari standar profesional.

3. Variabel Pengetahuan (X2) memiliki nilai t sebesar 3,894, nilai koefisiensi $\beta$ sebesar 0,403 . Hal ini menunjukan bahwa koefisien variabel (X2) berpengaruh positif terhadap audit judgement $(\mathrm{Y})$. Artinya bahwa auditor yang memiliki tingkat pengetahuan yang lebih tinggi akan membuat judgement yang tepat.

4. Variabel Pengalaman Auditor (X3) memiliki nilai $\mathrm{t}$ sebesar - 0,205, nilai koefisiensi $\beta$ sebesar - 0,033. Hal ini menunjukan bahwa koefisien variabel (X3) berpengaruh negatif terhadap audit judgement (Y).

Analisis Koefisiensi Determinasi (R2)

Koefisien determinasi bertujuan untuk mengetahui seberapa jauh kemampuan model dalam menerangkan variasi variabel independen (Ghozali, 2013). Nilai koefisien determinasi untuk variabel bebas lebih dari 2 menggunakan Adjusted $R$ Square sebagai berikut : 
Koefisien Determinasi (R2)

Model Summaryb

\begin{tabular}{|l|c|r|r|r|r|}
\hline Model & $\mathrm{R}$ & $\begin{array}{c}\mathrm{R} \\
\text { Square }\end{array}$ & $\begin{array}{c}\text { Adjusted } \\
\text { R Square }\end{array}$ & $\begin{array}{l}\text { Std. Error of } \\
\text { the Estimate }\end{array}$ & $\begin{array}{c}\text { Durbin- } \\
\text { Watson }\end{array}$ \\
\hline 1 &, $684^{\mathrm{a}}$ &, 468 &, 452 & 2,780 & 1,710 \\
\hline
\end{tabular}

a. Predictors: (Constant), TOTALPA, TOTALTK, TOTALPEA

b. Dependent Variable: TOTALAJ

\section{Sumber: Output SPSS 23.0 for windows}

Dari hasil perhitungan dapat diketahui bahwa koefisien determinasi (Adjusted $\mathrm{R}$ Square) yang diperoleh sebesar 0,452 . Hal ini menunjukan bahwa 45,2\% Audit Judgment dapat dipengaruhi oleh variabel Tekanan Ketaatan, Pengetahuan, dan Pengalaman Auditor sedangkan sisanya sebesar $54,8 \%$ Audit Judgment dipengaruhi oleh variabel variabel lainnya yang tidak diteliti dalam penelitian ini.

\section{Uji Statistik F (Uji Kesesuaian Model)}

Uji F statistik ini berguna untuk memperlihatkan apakah semua variabel independen yang dimaksud dalam penelitian ini memiliki pengaruh secara bersama-sama terhadap variabel variabel dependennya. Hasil perhitungan uji $\mathrm{F}$ ini dapat di lihat pada tabel berikut :

\section{Hasil Perhitungan Uji F (Secara Simultan)} ANOVA $^{a}$

\begin{tabular}{|r|r|r|r|r|r|}
\hline Model & $\begin{array}{r}\text { Sum of } \\
\text { Squares }\end{array}$ & Df & $\begin{array}{r}\text { Mean } \\
\text { Square }\end{array}$ & F & Sig. \\
\hline 1 Regression & 653,261 & 3 & 217,754 & 28,168 &, $000^{\mathrm{b}}$ \\
Residual & 742,129 & 96 & 7,731 & & \\
Total & 1395,390 & 99 & & & \\
\hline
\end{tabular}

a. Dependent Variable: TOTALAJ

b. Predictors: (Constant), TOTALPA, TOTALTK,

TOTALPEA

Sumber : Output SPSS 23.0 for windows
Berdasarkan hasil output penelitian, menunjukan nilai Fhitung sebesar 28,168 dengan tingkat signifikansi sebesar 0,000, kurang dari 5\% $($ sig < 5\%). Maka variabel Tekanan Ketaatan, Pengetahuan, dan Pengalaman Auditor secara bersamaan berpengaruh terhadap Audit Judgment.

\section{Uji Statistik $t$ (Uji Signifikan Parameter Individual)}

Uji t dilakukan untuk menunjukan seberapa jauh pengaruh satu variabel independen secara individual dalam menerangkan variabel - variabel dependen. Uji $t$ dalam penelitian ini dilakukan dengan membandingkan $\mathrm{P}$ value dengan tingkat signifikansi 0,05. Hasil untuk uji regresi parsial ini dapat dilihat pada tabel 4.15.

\section{Hasil Perhitungan Uji t Coefficients ${ }^{a}$}

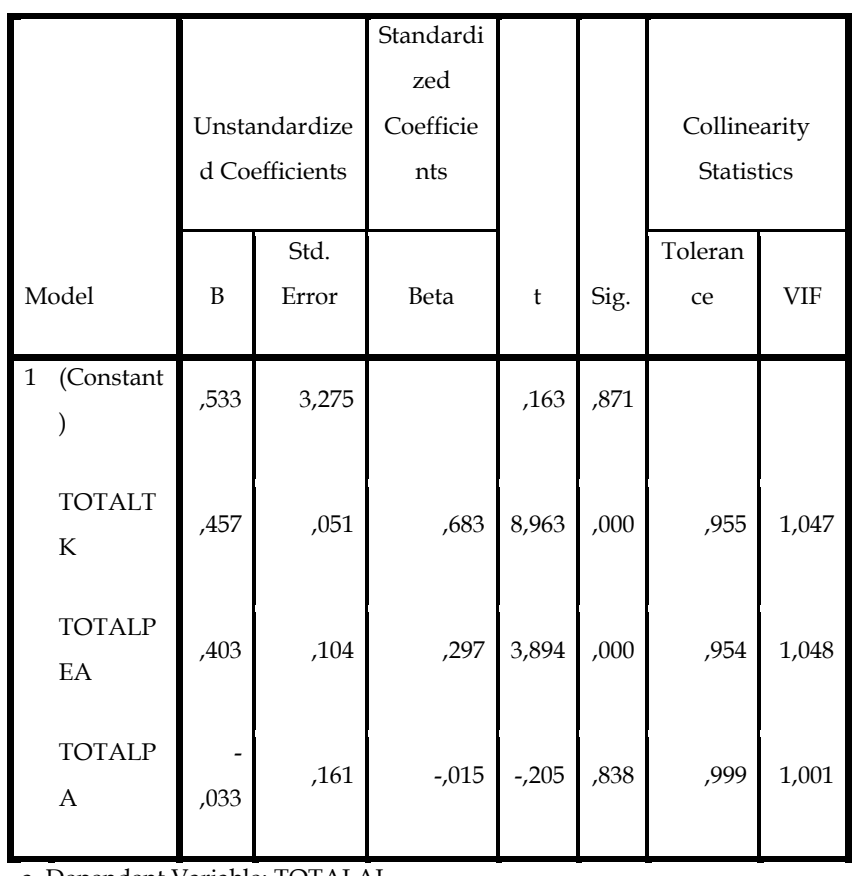

a. Dependent Variable: TOTALAJ

\section{Sumber : Output SPSS 23.0 for windows}

Pengaruh dari setiap variabel independen terhadap variabel dependen dapat dilihat dari arah tanda dan tingkat signifikansi (Probabilitas). Kedua variabel independen mempunyai pengaruh positif, variabel Tekanan Ketaatan dan Pengetahuan berpengaruh signifikan terhadap Audit Judgement. Hal tersebut dilihat dari nilai signifikan yang lebih kecil dari 0,05 sedangkan nilai signifikan dari Pengalaman Auditor lebih besar dari 0,05 dan itu berarti Pengalaman Auditor tidak berpengaruh secara signifikan terhadap Audit Judgement. 
1. Uji Variabel Tekanan Ketaatan (X1) terhadap Audit Judgement (Y)

Dari tabel diatas dapat dilihat bahwa hasil pengujian hipotesis Tekanan Ketaatan dalam tabel memiliki taraf signifikan sebesar 0,000 $<0,05$ yang memiliki arti hipotesis dalam penelitian ini Ha diterima.

2. Uji Variabel Pengetahuan (X2) terhadap Audit Judgement (Y)

Dari tabel diatas dapat dilihat bahwa hasil pengujian hipotesis Pengetahuan dalam tabel memiliki taraf signifikan sebesar 0,000 $<0,05$ yang memiliki arti hipotesis dalam penelitian ini Ha diterima.

3. Uji Variabel Pengalaman Auditor (X3) terhadap Audit Judgement (Y)

Dari tabel diatas dapat dilihat bahwa hasil pengujian hipotesis Pengalaman Auditor dalam tabel memiliki taraf signifikan sebesar $0,838<0,05$ yang memiliki arti hipotesis dalam penelitian ini Ha ditolak.

\section{CONCLUSION, IMPLICATION, SUGGES- TION, AND LIMITATIONS \\ Kesimpulan}

Dari analisis data diatas peneliti memberikan kesimpulan terhadap hasil penelitian sebagai berikut :

1. Hasil penelitian menunjukan tekanan ketaatan berpengaruh positif signifikan terhadap audit judgement, sehingga auditor junior lebih memilih untuk mentaati perintah atasan karena tidak ingin kehilangan pekerjaan dan melakukan apa yang di perintahkan klien karena tidak ingin kehilangan klien sehingga auditor dapat melakukan perilaku yang menyimpang dari standar profesional.

2. Hasil penelitian menunjukan pengetahuan berpengaruh positif signifikan terhadap audit judgement, maka dapat dikatakan apabila semakin tinggi tingkat pengetahuan seorang auditor maka semakin tepat atau baik judgement yang diberikan oleh auditor tersebut.

3. Hasil penelitian menunjukan pengalaman auditor berpengaruh negatif terhadap audit judgement, sehingga lamanya masa seorang auditor bekerja dan banyaknya jumlah penugasan yang diberikan kepada auditor tidak memberikan jaminan judgment yang diberikan oleh auditor adalah judgement yang tepat atau baik.
4. Tekanan Ketaatan, Pengetahuan dan Pengalaman Auditor berpengaruh secara simultan terhadap Audit Judgement.

\section{REFERENCES}

Ariyantini, Kadek Evi., Sujana, Edy., Darmawan, Nyoman Ari Surya. (2014). Pengaruh Pengalaman Auditor, Tekanan Ketaatan dan Kompleksitas Tugas Terhadap Audit Judgement. Jurnal Akuntansi Program S1, Vol 2. No.1.

Fitriana, R, Kamaliah dan Susilatri. 2014. Pengaruh Kompleksitas Tugas,Tekanan Ketaatan, Tingkat Senioritas Auditor, Keahlian Auditor, dan Hubungan dengan Klien Terhadap Audit Judgment.Volume 1, No. 2.

Fitriani Seni dan Daljono. 2012. Pengaruh Tekanan Ketaatan, Kompleksitas Tugas, Pengetahuan, Dan Persepsi Etis Terhadap Audit Judgment. Jurnal Akuntansi Universitas Diponegoro: volume 1, No.1.Hal 1-12.

Ghozali, Imam. 2013. Aplikasi Analisis Multivariate dengan Program IBM SPSS 21.Cetakan VII. Badan Penerbit Universitas Diponegoro : Semarang.

Institut Akuntan Publik Indonesia.2011.Standar Profesional Akuntan Publik, Salemba Empat, Jakarta.

Jamilah, Siti, Zaenal Fanani dan Grahita Chandrarin. 2007. Pengaruh Gender,Tekanan Ketaatan, dan Kompleksitas Tugas terhadap Audit Judgment. Simposium Nasional Akuntansi X Unhas Makassar.

Puspitasari Novianti Ika.2014. Pengaruh Gender, Tekanan Ketaatan, Kompleksitas Tugas, Pengetahuan, dan Persepsi Etis Terhadap Audit Judgment. Naskah Publikasi. Universitas Muhammadiyah Surakarta.

Putra Akbar Muhammad Tamara dan Rani Puspita.2016. Pengaruh Gender, Kompleksitas Tugas, Pengalaman Auditor dan Kompetensi Profesional Terhadap Audit Judgment.Vol 5, No.2

S. Ika Ardiani, Janie Dyah R.A, Ribka Sulistyanti.2011.The Influence of Gender, Obedience Pressure, Task Complexity, Experience, and Knowledge on Audit Judgement (Empirical Study on Accounting Firms in Central Java).

Sari Indah Permata.2016.Pengaruh Gender, Tekanan Ketaatan, Kompleksitas Tugas, Pengalaman Auditor, Pengetahuan Auditor dan Kompleksitas Dokumen Audit terhadap Audit Judgment.JOM Fekon. Vol. 3, No. 1. 
Sila Mursalim, Bambang Subroto, Zaki Baridwan, dan Aulia Fuad Rahman.2015. The Effect of Knowledge and Experience on Professional Auditor's Judgment: Study on State Auditor in Indonesia.Volume 3, No.10. Hal 98-106.

Tuanakotta, Theodorus M. 2015. Audit Kontemporer.Penerbit Salemba Empat: Jakarta.
Watloly Aholiab.2013. Sosio-Epistemologi Membangun Pengetahuan Berwatak Sosial.Penerbit Kanisius: Yogyakarta.

Yendrawati, R, dan Mukti, DK. 2015. Pengaruh Gender, Pengalaman Auditor, Kompleksitas Tugas, Tekanan Ketaatan, Kemampuan Kerja dan Pengetahuan Auditor Terhadap Audit Judgment.Vol.4 No.1. Hal 1-8.

Yustrianthe, R. H. 2012. Kajian Empiris Audit Judgment pada Auditor.Vol.2 No.2. Jakarta. 